\title{
Proper Beneficiary Selection:
}

\author{
Key Success of Farmers Poverty Alleviation Program
}

\author{
Sri Wahyuni*, Herlina Tarigan \\ Indonesian Center for Agricultural Socioeconomic and Policy Studies \\ IARD Ministry of Agriculture \\ Bogor, Indonesia \\ *maloleyayuk@yahoo.com, herlin4@yahoo.com
}

\begin{abstract}
Reducing poverty should be started from the agriculture sector, poverty alleviation programs for farmers had been implemented in two-phase, during 1979-2005 and in 20062014 with low achievement as 33,3\% and 14,6\%. In 2018 a program called Bedah Kemiskinan Rakyat Sejahtera (BEKERJA) was implemented, therefore should be studied for based strategy in the new Development Cabinet (2019-2024). This paper focused on the key success of the program that could be replicated for future strategy. The research was conducted in East Java during 2019, respondents were representative's institution from the national to village level who involved in the program. Results showed that the key success of the program was the proper institution which really in accordance with the commodities used as the spearhead of the program and the beneficiaries were professional in the management of the commodities provided by the program. Best beneficiary performance managed the packed professionally and reach income and have an additional animal protein source as the goal of the program, moderate beneficiaries consumed the eggs for the family source of animal protein while the worst beneficiaries only get a barn left. The implication was the key success of the program were the selection of proper institution and beneficiaries of the program.
\end{abstract}

Keywords-poverty alleviation, selection, beneficiaries, BEKERJA

\section{INTRODUCTION}

Poverty alleviation is the first out of 17 Sustainable Development Goals (SDG's) objectives [1] and 67 years before the UN conference Indonesia has committed to reaching the welfare of all people which is stated in the Constitution of the Republic of Indonesia or Undang Undang Dasar (UUD) 1945. This commitment is supported by facts that the Poverty Alleviation Program has been implemented throughout the history of the leaders of the Republic of Indonesia [2], with 33 programs from 1970 to 2019.

Poverty in rural areas is much higher than in cities, in September 2018 the poverty in rural areas was $13.10 \%$ while in urban areas $6.89 \%$ [3]. This fact indicates that efforts to reduce poverty must start from rural areas especially in the agriculture sector [4]. Special poverty alleviation program that directed to farmers had been implemented by the Ministry of Agriculture were the Project for Increasing Small Farmers and Fishermen's Income or Program Pembinaan Peningkatan Pendapatan Petani

Nelayan Kecil (P4K) during 1979-2005 with the achievement of 33,3\% [5]. In 2006 a program named the Rural Agribusiness Development Program or Program Pengembangan Usaha Agribisnis Perdesaan (PUAP) had been implemented until 2014 with achievement reported by Zulkifi [6] as 14,6\%. The achievement was based on the goals' indicator, in which beneficiaries could create a Micro Finance Agricultural Institution or Lembaga Keuangan Mikro Agribisnis (LKMA).

In early 2018 the Ministry of Agriculture [7] launched a new poverty alleviation program called "Tackle poverty for People Welfare" or Program Bedah Kemiskinan Rakyat Sejahtera (BEKERJA). Since previous research had not covered the report achievement of the BEKERJA Program and 2019 is the start of the new Development Cabinet Program (2019-2024) in which a new strategy for poverty alleviation for farmers is needed, therefore BEKERJA program as the last program should be studied. Especially since Indonesia is keeping struggling to alleviate poverty, especially for farmers.

Pay attention to reports about the low success of the previous poverty alleviation programs had been described, which had been explained the problem and obstacles as based on the strategy to alleviate farmers' poverty, instead this paper trying to identify the key strategy to achieve a successful poverty alleviation program. Through the success story, lessons learned could be referred, adopted, and replicate for the future poverty alleviation program.

\section{Methodology}

\section{A. Theoretical Framework}

The goals of the BEKERJA Program based on Minister of Agriculture Regulations No. 27/PERMENTAN/RC.120/5/2018 was to maximize the use of farmers' yard to increase their income and source of animal protein consumption. The government provided input of the yard farming packages that consist of 50 chickens, ready barn, feed, and facilitation of the 
farming. The expectations for additional income was 2 to 2.5IDR million per month [8]. From this additional income, the family will come out of the poverty line permanently since the poverty line or Garis Kemiskinan (GK) in Indonesia is IDR401,220/capita/month, consisting for food IDR294,806 plus non-food IDR106,414/capita/month so that with 4 to 5 family members it reaches IDR1.84 million/household /month. If the income of the farmers' household less than IDR1.9 million, they are categorized as poor families [9]. These two goals were used as indicators of the success of the BEKERJA program.

\section{B. Data}

Data were collected during September 2019 in East JavaProvince based on a report that East Java has a special approach in implementing the BEKERJA program. The information collected from respondents that selected based on Snow Ball refer to Parker et al., [10]. The first respondent was the representative of the main responsible institution in BEKERJA namely the Center of Veterinary Pharmacology or Pusat Veteriner Farma (PUSVETMA) as the implementing program. Second respondents were the representative of the District level namely the Food Security and Animal Husbandry Services or Dinas Ketahanan Pangan dan Peternakan (DKPP) of Jember District. It was reported that there are three Subdistrict that had received the BEKERJA program as mentioned in The Ministry of Agriculture Act (Permentan) No.27/PERMENTAN /RC.120/5/2018) such as Gumukmas, Ledokombo, and Kalisat.

Respondents in the sub-district level represented by the staffs in charge on the BEKERJA program, completed with respondents at the village level which are considered as the representative beneficiaries namely: Sumber Lesung Village from Sub-district of Ledokombo, Karangrejo Village from Sub-district of Gumukmas, and Sumber Ketempa Village from Sub-District of Kalisat. An in-depth interview based on a structure questioner was conducted with three beneficiaries in each village representing low, medium, and good achievement during the field survey. These different ways of collecting data, which is collected by a team consist of different expertise (sociology, economics, and policy analysts) is a means to implement The Triangulation Principle of Rapid Rural Appraisal [11]. The main questions consisted on how farmers solved their problems encountered during the programs' implementation to achieve the goals of the program. Data and information were analyzed qualitatively and presented descriptively refer to Saputro [12].

\section{RESULTS}

\section{A. Province Level}

East Java is one out of 10 provinces of program BEKERJA locations in 2018 [13] with the program executor PUSVETMA as the Technical Implementation Unit of the Directorate General of Animal Husbandry and Animal Health. Meanwhile, the program implementation at the district level was the
Department of Food and Animal Security which is officially under the Provincial Agriculture Office which unfortunately had not been included at the beginning of the program implementation. This condition inhibits good coordination during the implementation of the program. Additionally, the head of the Jember district or Bupati reminds that every implementation of the development program could not directly appoint a certain agency or special office but first should ask permission to Bupati. Information from province level illustrate how important is the selection of the integrated institutions who should responsible in a program.

There are three districts of East Java that received BEKERJA Program namely Bondowoso, Jember and Lumajang. Each district has poor family or Rumah Tangga Miskin (RTM), respectively as 152,348, 295,291 and 132,696 RTM and the targeted of beneficiaries respectively were $12.915,15.606$ and 14.029 RTM, meaning that only 8.4, 5.3 and $10.5 \%$ from the total number of household from each district. Therefore, in implementing the BEKERJA program, the beneficiaries should be selected carefully to avoid social jealousy. Special approach had been conducted by the head of Jember District and reported had taken three months for the verification of beneficiaries. Therefore, the implementation of the program that should began in 23th of May postponed to August when the verification finished. Finally, when the chickens delivered during September which was the rainy seasons, caused high mortality reach to $50 \%$ during the 10 days after dropping and in the last week of September the beneficiaries who still raise the chicken only about $20 \%$ left. This information reminds again on how important is the selection of the beneficiaries to achieve the goals of the program.

The important of the beneficiaries selection was again reported at the province level who considered that BEKERJA program not implemented efficiently, and perceived that it would be better if the program beneficiaries integrated to the existing program beneficiaries such as the Sustainable Food Household Area or Kawasan Rumah Pangan Lestari (KRPL) that has been showed good impact [13]. The considerations are: 1) There are three classifications of KRPL groups such as beginner, growth and the independent. The independent group would be the appropriate beneficiaries since already showed their capability in the management of the initial capital through good networking internally with the members and other agriculture-related businessman. 2) BEKERJA has similar goals with KRPL, BEKERJA to increase of animal protein intake and family income from egg sales while KRPL to reduce expenditure and increase family nutrition. These two programs could be integrated to get maximum achievement with an efficient use of resources in terms of the package utilization and assistant. 3) The majority assistants of BEKERJA program are Agricultural Extension Workers or Penyuluh Pertanian Lapangan (PPL) who are holding their respective institutions responsibility so that the task is very burdensome for them. While the additional incentives provided for with responsibility of reporting the progress of the program that should be reported to the district only IDR500 thousands. 
Considering those experience, the implementation of BEKERJA in East Java for 2019 is given to KRPL group and the program named the non-regular KRPL while groups that do not receive chicken packages named as regular group. In 2019 East Java Province will implement regular KRPL of 76 groups in certain locations while non-regular KRPL (KRPL plus BEKERJA) 104 groups in different locations. The funding provided is also different, the regular group receives IDR50 million per group while the non-regular IDR65 million with a minimum of 30 members in a group with 1.350 chickens per group and freedom in designing the barn, could be communal or individual barn and no definite number between the hens and cock. This plan was supported with report that the chicken from BEKERJA is originally from native chicken with no barn but raised expensively [14].

\section{B. District Level}

1) Regional Planning Agency or Badan Perencanaan Daerah (BAPEDA): The head of Jember district (Bupati) has a commitment that to achieve a success development program (including BEKERJA) should be: 1) No conflict and illegal issues in selecting the beneficiaries and 2) Delivered on time in appropriate quantity as well as quality. To avoid conflict and illegal issues, a special team was formed under decree No. $188.45 / 470 / 1.12 / 2018$ [15] to verify and validate (Verivali) the data of RTMP from the Ministry of Agriculture. The decree established since Jember Regency under the authority of Bupati that means the implementation of BEKERJA program under the authorization of Bupati through the Regional Planning Agency or Badan Perencanaan Daerah (BAPEDA). Bupati reminds that every implementation of development program could not directly appoint the related agency or special office but first should ask permission to Bupati.

The research team who only knew that the related institution of BEKERJA program in district level is the Food Security and Animal Husbandry Services or Dinas Ketahanan Pangan dan Peternakan (BKPP) and information from province level that Jember district conducted special approach in the selection of beneficiaries were not realized that in conducting the Focus Group Discussion (FGD) should invite the representative from $B A P E D A$ and also conduct the FGD at $B A P E D A$. Therefore, all FGD participants who were ready to start the discussion at BKPP suddenly have to move to BAPEDA Office. This was a very valuable finding on how important is procedure in the selection of appropriate institution selection for the success of the program. During the FGD, the research team were explanted about the selection steps of the beneficiaries of program BEKERJA as follows.

The Perivale team consist of 90 personals such as steering committee, chairman, program implementers, data management and surveyor (Table 1) in which the steering team consists of the district head, the head of the prosecutor's office, the head of the police station and chaired by the district secretary. The team also included staff of Social Services Office, Food Security and Animal Husbandry Department as well as the Food Crop Office, Horticulture and Plantation Services as the deputy chairman.

At district level the personals consist of all heads of subdistrict or Camat from all sub-district (Kalisat, Ledokombo and Gumukmas), Social staff in the sub-district level or Tenaga Kerja Sosial Kecamatan (TKSK) from all Sub-districts, head of Military District Commander or Komandan Distrik Militer (Dandim), Military Rayon Commander, Resort Police Chief or Kepala Polisi Sektor (Kapolsek),Sector Police Chief or Kepala $\checkmark$ Polisi Sektor (Kapolsek) from 3 Subdistricts, UPKK (Unit Pengelola Keuangan Kegiatan) representatives, from 30 Villages, assistants from 3 Subdistricts.

TABLE I. TEAM OF FARMERS' BENEFICIARIES SELECTION IN BEKERJA PROGRAM (JEMBER DISTRICT 2018)

\begin{tabular}{|c|c|c|}
\hline Level & Personal & $\begin{array}{l}\text { Number of } \\
\text { Personal }\end{array}$ \\
\hline District & Bupati ( head of Jember district ) & 1 \\
\hline \multirow{9}{*}{$\begin{array}{l}\text { Sub- } \\
\text { District }\end{array}$} & Steering & 4 \\
\hline & Chairman & 6 \\
\hline & Vice chairman & 5 \\
\hline & Field coordinators & 9 \\
\hline & Program executor & 4 \\
\hline & Data management & 2 \\
\hline & Surveyor: & \\
\hline & $\begin{array}{l}\text { 1.Military } \\
\text { (BABINSA) }\end{array} \quad$ Regional $\quad$ Command & 30 \\
\hline & $\begin{array}{l}\text { 2.Police fostering orderly public security } \\
\text { (BHABINKAMTIBMAS) }=30 \text { personal }\end{array}$ & 30 \\
\hline Total & & 90 \\
\hline Village & $\begin{array}{l}\text { Head of neighborhood or Ketua RT } \\
\text { Head of neighborhood residents or Ketua } \\
\text { RW }\end{array}$ & \\
\hline
\end{tabular}

REGIONAL PLANNING AGENCY (BAPEDA JEMBER, 2018)

At village level, the head of neighborhood or ketua Rukun Tetangga $(R T)$ and the household organization or Rukun Warga $(R W)$ also participate in the selection of the Beneficiaries. There were social and technical parameters or requirements that should be owned by the beneficiaries. The social parameter were the beneficiaries must have identity cards of: a) Indonesia Healthy Card or Kartu Indonesia Sehat (KIS); b) Indonesia Smart Card or Kartu Indonesia Pintar (KIP); c). Prosperous Family Card or Kartu Keluarga Sejahtera $(K K S)$ and d) Pra welfare Family cards or Kartu Keluarga Harapan (KKH) and receiver of rice for welfare card or beras sejahtera (Rastra). The technical aspects include: a) Land Status (Owner, renters or others) Lease with along with proven documents; b). The area of land occupied (Minimum yard area: $31 \mathrm{~m} 2$, land for barn least $6 \mathrm{~m} 2$, yard for planting Vegetable minimum $25 \mathrm{~m} 2$. c). Water Source (Well or PDAM or Non-PDAM, River / Channels) and e). Chicken Livestock owned should be less than 25 chickens.

Verivali were start on July 20th 2018, means that from the start of program implementation (end of March) took three months' institutional procedure plus one month to finish the appropriate selection of beneficiaries (finish on August 9th 2018). The selection result from 15.606 RTM in the list of 
beneficiaries proposed by the Minister of Agriculture only 12.698 who appropriate as beneficiaries because the other $18.6 \%$ RTM status were not qualify according to the criteria of selection. Based on social criteria $4,5 \%$ not qualify, $1,6 \%$ for technical criteria, and $8.0 \%$ for both social and technically criteria and $4.4 \%$ RTM were not found in the villages [16]. This result was reported to Director General of Animal Husbandry and Animal Health the Ministry of Agriculture as PJ and PUSVETMA as the program executor (Letter No. 050/1251/411/2018)

\section{2) Department of Food Security and Animal Husbandry or} Dinas Ketahanan Pangan Dan Peternakan (DKPP): The DKPP Confirmed were received BEKERJA program from the responsible institution in the implementation of the program. PUSVETMA have distributed the full package of BEKERJA program for 12.660 RTMP as the result of beneficiaries verivali that consist of 50 chickens (30 females and 20 male) in one -month-old of crossbreed between layer and native chicken called Jowo Peranakan (Joper) plus 200kg of feed for each beneficiariy. Before dropping the chickens, the ready barn were dropped to all the beneficiaries along with drinking equipment and medicines.

The program begins with Verivali of RTMP level which is carried out by the neighbor head or ketua rukun tetangga (RT) and the head of citizen association or ketua rukun warga $(R W)$. All the beneficiaries receive a socialization DKPP, Village Regional Military Command or Bintara Pembina Desa (BABINSA) and Public Order Security or Keamanan dan Ketertiban Masyarakat (KANTIBMAS), known as the Three Pillars in the development. Chickens dropping delivered in 3 periods, first dropping were attended by Bupati and the head of PUSVETMA and all the beneficiaries.

The following was the way how farmers had tried to reach the goals of the program in all problems during the implementation such as:

- Raising chicken was really something new for the majority of the beneficiaries, unfortunately experiences on chicken raising were not considered as requirement in the technical criteria in the selection of the beneficiaries. Moreover, socialization only conducted once before dropping the package and no brochure of chicken farming were distributed. Therefore, the farmers have not understood well about the appropriate raising management. What farmers did when they face problem, they reported to the sub-village head or ketua dusun who had no receive any socialization related to the program.

- An Assistant called finance management unit Activity or Unit Pengelola Keuangan Kegiatan (UPKK) selected from the villages officer has too much responsibility such as 100 RTM even some have to handle 600 RTM so that not all RTMPs could be monitored.
- The feed runs out before the chicken produce eggs, that my caused by their lack of knowledge on feeding system since raising native chicken no need special feed except just whatever the farmers have (only when they have food left over) even chickens find their own food around the house and even the neighbor's yard. This fact caused the chickens dead or sold if there was a change since often chickens found already weak and suddenly die.

- At the same time, the timing of chicken dropping was not in good seasons since September is the beginning of rainy season which causes the condition of chickens to be less healthy and caused high mortality is the beginning of dropping.

- Farmers would not consume the chicken because the chicken looked big of the thick fur and less tasty compared to the original native or Kampung chicken.

The above five kinds of problem were actually caused by the inability of the beneficiaries in raising chickens.

\section{Sub-District Level}

The chickens number distribute to beneficiaries were different with the design (48 females and 2 male chicken) but beneficiaries received in very varies composition, around 30 female and 20 male hens distributed between 26th September to end of November (Table 2)

TABLE II. THE DESIGN AND IMPLEMENTATION OF THE PACKAGES IN EACH SUB-DISTRICT

\begin{tabular}{|c|c|c|c|c|c|}
\hline \multirow{2}{*}{ No } & \multirow{2}{*}{$\begin{array}{l}\text { Package/ } \\
\text { input }\end{array}$} & \multirow{2}{*}{$\begin{array}{l}\text { Design } \\
\text { Criteria }\end{array}$} & \multicolumn{3}{|c|}{ Implementation in Sub-district } \\
\hline & & & $\begin{array}{c}\text { Gumuk } \\
\text { Mas }\end{array}$ & Ledokombo & Kalisat \\
\hline \multirow[t]{5}{*}{1} & Chickens & & & & \\
\hline & Breed & Joper & yes & Yes & Yes \\
\hline & Female (tail) & 42 & 30 & 20 & \multirow{3}{*}{$\begin{array}{l}\text { Could } \\
\text { not } \\
\text { identify }\end{array}$} \\
\hline & Male (tail) & 8 & 20 & 30 & \\
\hline & Age (weeks) & 4 & Yes & Yes & \\
\hline \multirow[t]{3}{*}{2} & Feed & & & & \\
\hline & Volume (kg) & 200 & 200 & 200 & 200 \\
\hline & Used for & 4 months & 3 & $2-3$ & $2-3$ \\
\hline 3 & Barn & Ready & Ready & Ready & $\begin{array}{l}\text { IDR } \\
500.000\end{array}$ \\
\hline 4 & $\begin{array}{l}\text { Advisor } \\
\text { /socialization }\end{array}$ & $\begin{array}{l}\text { Staffs of } \\
\text { Animal } \\
\text { Husbandry } \\
\text { Division }\end{array}$ & Once & Once & Once \\
\hline 5 & Assistance & $\begin{array}{l}\text { District } \\
\text { Social } \\
\text { Welfare } \\
\text { Workers } \\
\text { (TKSK) 1/ } \\
\text { ub-district }\end{array}$ & $\begin{array}{l}\text { Yes } \\
\text { (some) }\end{array}$ & $\begin{array}{l}\text { Yes (after } \\
\text { most } \\
\text { chickens } \\
\text { died) }\end{array}$ & $\begin{array}{l}\text { Yes } \\
\text { (after } \\
\text { most } \\
\text { chickens } \\
\text { died) }\end{array}$ \\
\hline
\end{tabular}

The age of chicken also not as designed, most chickens are small even farmers could not identify which one is hen or cock. Barns were design ready to used but in the implementation 
same farmers received in cash IDR500.000. Feed were provided for about two months $(200 \mathrm{~kg})$ in twice dropping. The highest mortality $(50 \%)$ found from the first to 10 days after the dropping that caused by the improper timing of delivery and additionally the smells of wet bamboo in the barn that cause poisoning. Based on report in sub-district level, the number of beneficiaries who still raise chickens were only about $10-20 \%$ but the number of survive chickens were very varies around 2 (two) to 7 (seven) layers.

Based on the information from the district and sub-district, modification approach in data collection at village level were decided by the research team, such as doing field visit to beneficiaries which perform best achievement, moderate and worst. The best achievement found in the Gemukmas, moderate in Kalisat and the worst in Ledokombo as presented in the following description.

\section{Best Beneficiaries Performance}

In Gumukmas sub-district, beneficiaries with all chickens still alive is managed by a farmer (Mr. Timbul) who experienced in raising chickens. Before receiving chicken from BEKERJA, he raises native chickens and Bangkok chickens. His household source of income is from three source such as: 1) Marketing agricultural product, mainly fruit and vegetable to the nearest market. 2) Raising cattle he got through sharing system with the owner (Head of the village). These two activities are possible since he has enough home yard (about $500 \mathrm{~m}$ square) with a permanent house in $80 \mathrm{~m}$ square built trough House Improvement Program or Program Bedah Rumah. His other source of income is raising chickens that is fully supported by his wife who stay at home as reported by Tarigan and Wahyuni [17] that although the list of beneficiaries the name is head of household in fact $85 \%$ of wives were responsible for the chickens raising. The wife taking care for the chickens' health such as when the chicken just dropped and look so weak she gave water sugar and sometimes gave turmeric water mixed with tamarine and sugar cane during the weather not good. She also provides other medicine such as eye drops and nose drops for snot which is advice by the assistants who come to her house for controlling the cattle. The detail management and achievement presented in Table 3, which proved that income form BEKERJA chicken could alleviate the beneficiaries for poverty as the income reached IDR 2.362.000 which confirmed to [8] that the income of BEKERJA between IDR 2 to 2.5 million. Table 3 also showed that the feed only enough for 3 months that's why they sold the chickens for the feed that cost IDR 22.000 per day and fortunately money from selling the production enough for buy for two months feed requires.

Information in Table 3 showed that in each egg production cycle only 5 eggs are hatched or sold, the recipient explaining that other egg productions was consumed by the family. This fact showed that raising chickens from the BEKERJA program can help increase the household consumption from animal protein.
TABLE III THE BEST MANAGEMENT IN RAISING CHICKENS FROM BEKERJA PROGRAM IN GEMUKMAS SUB-DISTRICT 2020

\begin{tabular}{|c|c|c|c|c|}
\hline No & Allocation of Chickens & Male & Female & $\begin{array}{c}\text { Income } \\
\text { (IDR) }\end{array}$ \\
\hline \multicolumn{5}{|c|}{ I Cycle with chicken from BEKERJA } \\
\hline 1 & From BEKERJA & 18 & 32 & \\
\hline 2 & $\begin{array}{l}\text { Sold in } 3 \text { months old IDR } \\
33.000 / \text { chicken }\end{array}$ & 17 & 25 & 1.386 .000 \\
\hline 3 & Used as cock & 1 & 0 & \\
\hline 4 & Used as layer & 0 & 7 & \\
\hline \multirow[t]{3}{*}{5} & $\begin{array}{l}\text { Eggs (5eggs from each } \\
\text { layer @ IDR 1.500) }\end{array}$ & & & 52.000 \\
\hline & Total income & & & 1.438 .500 \\
\hline & \multicolumn{4}{|c|}{$\begin{array}{l}\text { No more feed, therefore income used to buy feed for the next } \\
\text { raising period@ IDR } 22.000 / \text { day= } 65 \text { days. Means income enough } \\
\text { for buy feed during the next } 2 \text { months }\end{array}$} \\
\hline \multicolumn{5}{|c|}{ II Cycle, only with 7 layers and 1 cock } \\
\hline 1 & $\begin{array}{l}\text { Eggs (5eggs from each } \\
\text { layer @IDR 1.500) }\end{array}$ & & & 52.500 \\
\hline \multirow[t]{2}{*}{2} & $\begin{array}{l}\text { Hens, after } 2 \text { months old } \\
(10 \text { hens from each layer @ } \\
\text { IDR 33.000) }\end{array}$ & & & 2.310 .000 \\
\hline & Total income & & & 2.362 .500 \\
\hline
\end{tabular}

This best beneficiary's performance proved that to achieve to programs' goals, a professional criteria and responsible labor in raising chicken is very important that should be included in the beneficiary's selection.

\section{E. Moderate Beneficiary's Performance}

Beneficiaries in Ledokombo sub-district received the chickens in two different time within two weeks, chickens in the second dropping were smaller with high mortality due to rainy season and found that the dead caused of snots while drugs were not available yet. Farmers knew this symptom after received video along with the medicine from an assistant as the respond from the assistant report. Rising chickens were considering very difficult, especially with 50 tails, caused they usually only has 2 to -5 chickens without providing feed. Since the chickens were too small they could not identify the sex until two months after the dropping and found that there got 30 tails of male chicken. Feed were run out before chicken produce eggs and they do not have money to buy therefore farmers just sell or let the chicken die. A farmer who work at Rice Milling Unit (RMU) were lucky since he got free rice brand to feed the chickens therefore still have 2 layers with some eggs in the barn, one egg found broken during survey and a chicks die from being squeezed on the floor of the cage and then stepped on by other chickens. This could have happened because barn located opposite the house, alongside the main road since farmer did not have enough yard to put the barn. There was no information about the additional income he got from the raising chickens since he has never sell the chicken. However, his family have consumed the eggs from the layer production and lucky enough to receive support from BEKERJA program. The description about moderate beneficiary also proved that beneficiary of the program should be professional in raising the chicken. 


\section{F. The Worst Beneficiaries Performance}

In Kalisat Sub-district, the beneficiaries first receive money for the barn IDR500 000/RTM. There was assistant who monitored on the feasibility of the barn. After the barn ready chickens was dropped in October (50 chickens) in unidentified sex along with $100 \mathrm{~kg}$ of feed that should be enough for 60 days and the other $100 \mathrm{~kg}$ were given in the next month. When farmer's runout of feed before chicken produce any eggs, they just let the chickens died. A farmer's experience with mix disinfectants in the water drink for the chickens' and caused all chickens died. Farmers also perceive that chicken deaths caused of poisoned come from smells of bamboo which is still new and wet. The worst beneficiary's performance only got the remain empty barn that could be used in sometimes they want to raise another chicken.

This worst beneficiary's performance illustrates that beside the professional criteria for the beneficiaries, timeliness and suitability of the quantity and quality of inputs from the program are very important in achieving the success of a program.

\section{CONCLUSION}

The proper beneficiary's selection start from province until village level were the key success of a program. At province level, responsible institution should be properly link with the program activities. At district level, the first beneficiary should be the the Regional Planning Agency, the responsible institution in every development program. At sub-district level and village level, beneficiaries should have professional ability and labor who responsible in the management on the program input.

A lesson learned derived from best beneficiary's performance proved that BEKERJA program could tackle poverty since the poverty line of income IDR1.84 million/household/month and provide family source of animal protein consumption. The moderate beneficiary's performance only could have eggs for the family source of animal protein and the worst beneficiaries only got barn that could be used for raising other chickens since standard barn reach cost for at least IDR1.500 million.

Conclusion, the key success in BEKERJA program is proper selection of the beneficiaries from province to village level, especially the capability of the program beneficiaries supported timeline input in dropping and quantity as well as quality of the input.

\section{REFERENCES}

[1] United Nations Organization, "The sustainable development goals," [online]. Retrieved from www.un.org > sustainabledevelopment , sustainable-devel
[2] P. Situmorang, "Peek at the poverty alleviation program from the era of President Soeharto to Jokowi". Mengintip program pengentasan kemiskinan sejak era Presiden Soeharto hingga Jokowi," [online]. Retrieved from https://www.merdeka.com. Downloaded tgl 24 February 2019.

[3] Central Bureau of Statistics."National socio-economic survey". Biro Pusat Statistik [BPS]. Survei Sosial Ekonomi Nasional Maret 2018. No. ID: 00-SUSENAS-2018-MARET-M1-KOR 2018.

[4] T. Herlina, P. Simatupang, S. Wahyuni and I. Maulana, The strategy of poverty alleviation in agriculture and villages. Strategi penanggulangan kemiskinan di pertanian dan perdesaan. Jakarta: Laporan Penelitian, Pusat Sosial Ekonomi dan Kebijakan Pertanian. Kementerian Pertanian, 2019, p. 150.

[5] R. Hulmizan, "Analysis of the implementation of the small farmerfisherman income improvement program (P4k) in Pulau Lawas Village, Bangkinang Seberang District, Kampar regency. Analisis Pelaksanaan Program Peningkatan Pendapatan Petani-Nelayan Kecil, (P4k) Di Desa Pulau Lawas Kecamatan Bangkinang Seberang Kabupaten Kampar," [online]. Retried from http://repository.unand.ac.id/id/eprint/8107. 2011.

[6] Zulkifli, "Evaluation of the success of the puap program (rura agribusiness development. evaluasi keberhasilan program puap (pengembangan usaha agribisnis perdesaan," [online]. Retrieved from https://bangazul.com/evaluasi-keberhasilan-puap-pengembangan-usahaagribisnis-perdesaan/. 2013

[7] Ministry of Agriculture. "Guidelines for the implementation of BEKERJA Program" .Goverment Regulation. No.27/Permentan/RC/120/5/2018

[8] T. Reisha "Ministry of Agriculture work program called can eradicate poverty". "T. Program Bekerja Kementan Disebut Bisa Entaskan Kemiskinan," Detik Finance Berita Ekonomi, Bisnis, [onine]. Retried from https://finance.detik.com/berita-ekonomi-bisnis/d4564892/program-bekerja-kementan-disebut-bisa-entaskan-kemiskinan

[9] Central Bureau of Statistics. People welfare indicators. $252 \mathrm{pp}$. Publication No 07330.1914. 2019

[10] C. Parker, S. Scott, and A. Geddes, Snowball sampling. SAGE research methods foundations, 2019.

[11] D. Faturrochman, "PRA dan RRA dalam Pembangunan," [online] Retrieved from aturrochmandaster.blogspot2015.com/2015/7.Pra- rradalampengenbangan.html.

[12] T. Saputro, "Metode Pemberdayaan Masyarakat (RRA dan PRA)," [online]. Retrieved from https://www.ilmuternak.com/2015/02/metodepemberdayaan-masyarakat -rra-pra.html.

[13] Directorate General of Livestock Services and Animal Health. Ministry of Agriculture. "Technical guidance for BEKERJA program". Petunjuk teknis program BEKERJA, Jakarta. 2018.

[14] N.A.T. Desy, "The Implementation of Policy on KRPL Program. Implementasi kebijakan program KRPL dalam meningkatkan kesejahteraan keluarga," vol. 1, no. 1, pp. $71-87,2019$.

[15] Food Secutiry and Animal Husbandry Services. "Report of BEKERJA program,” Dinas Ketahanan Pangan dan Peternakan. Laporan program BEKERJA, 2018

[16] Regional Planning Agency (Badan Pemerintah Daerah) Kabupaten Jember. "Verification and validation for poor household of BEKERJA program of the Ministry of Agriculture" Verifikasi dan Validasi (Vervali) Rumahtangga Miskin Program Bekerja Kementerian Pertanian.. Lampiran Surat Bupati Jember Kepada Menteri Pertanian.

[17] H. Tarigan, and S. Wahyuni, "Women farmers focus strategy to achieve poverty alleviation and sustainable agriculture," Proceeding International Conference on Green Agro-Industry, vol. 4, 2020 